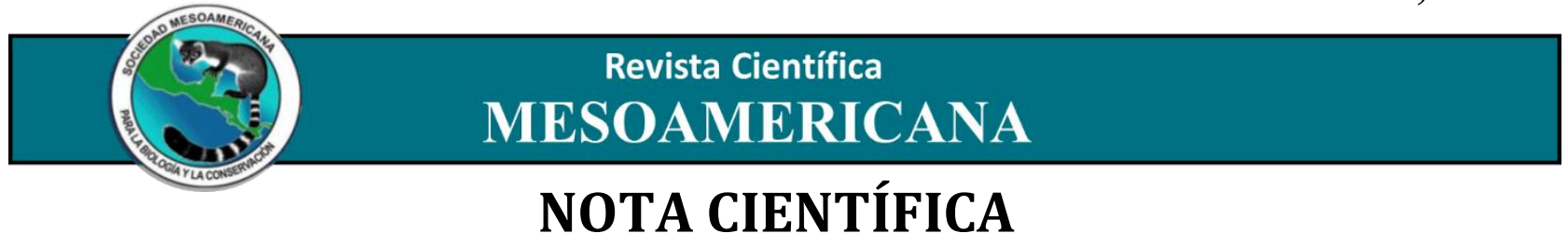

\title{
Report of a serendipitous encounter with a melanistic Jaguar in Darién (3 May 2019)
}

\author{
Orlando 0. Ortiz ${ }^{1}$ (D), Rebecca Quijano², Rogemif Fuentes ${ }^{3}$, Guido Berguido ${ }^{4} \&$ Ricardo $^{2}$ \\ Moreno $^{5,6^{*}}$ \\ 1 Universidad de Panamá, Estafeta Universitaria, Panama City, Panama. \\ ${ }^{2}$ Universidad Autónoma de Chiriquí, David City, Chiriquí, Panama. \\ ${ }^{3}$ Los Naturalistas, P.O. Box 0426-01459, David City, Chiriquí, Panama. \\ ${ }^{4}$ Adopt a Panama Rainforest Association (ADOPTA), P.O. Box 0801-00051, Panama City, Panama. \\ ${ }^{5}$ Fundación Yaguará Panamá, Ciudad del Saber Edificio 181, Panamá. \\ ${ }^{6}$ Smithsonian Tropical Research Institute, Balboa/Ancón, Panama. \\ *Corresponding author: Ricardo Moreno, rmorenopan@gmail.com
}

Fecha de Recepción: 18-XII-2019. Fecha de Aceptación: 15-VI-2019. Fecha de Publicación: 29-VI-2020.

In Panama, large carnivore species are represented by Canidae and Felidae. Among the Felidae, jaguars (Panthera onca) represent the largest cat in the Neotropics (Sunquist \& Sunquist, 2002; Jędrzejewskia et al., 2017) and the third largest in the world. Wozencraft (2005) recognized nine subspecies of jaguar, but recent morphometric and molecular studies suggest that it is actually a monotypic species, which occurs from Arizona through Central America, all the way down to northern Argentina (Kitchener et al., 2017). Unfortunately, the continuous loss of natural areas has reduced as much as 55\% of their historical range of occupation (Seymour, 1989; Sanderson et al., 1999; Zeller, 2007; Jędrzejewski et al., 2018). Currently, much of the usual jaguar habitats have been transformed into agricultural areas, cattle ranching, and human settlements, bringing jaguars and humans into conflict (Polisar et al., 2003; Moreno et al., 2016b). Panama does not escape from this negative reality, since natural populations of jaguars have been declining in the last decades (Meyer et al., 2015, 2016). The most relevant factors leading to the decrease of jaguar populations in Panama are habitat loss, conflicts with humans (mainly cattle ranchers) due to hunting of their natural prey and the use of their body parts and organs (Moreno pers. obs.; Moreno et al., 2015, 2016a, 2016b). Currently, the IUCN classifies the jaguar as near threatened (NT, Quigley et al., 2017) and in Panama it is considered an endangered species (EN, MiAmbiente, 2016).

Jaguars are an important component of the big mammals in Neotropical ecosystems, occupying the position of top predator; they are considered an umbrella species. Their distribution is mainly tropical, at low population densities (Silver et al., 2004; Reid, 2009; Moreno \& Meyer 2016), across several types of habitats, usually below 1800 m (Seymour, 1989; Moreno et al., 2016a); some specimens from Panama have been spotted at higher altitudes (3200 m; Moreno et al., 2016a). They can occupy montane forests, lowland evergreen forests, dry deciduous forests, mangrove forests, arid scrub and swampy grasslands (Sunquist \& Sunquist, 2002; Moreno et al., 2016a). They have been characterized as opportunistic predators, feeding primarily on medium to large preys, adapting their diet to local conditions (Lopez-Gonzalez \& Miller, 2002; Moreno, 2006). They are usually solitary and 
nocturnal, but in some places they can be diurnal, depending on the activity of its prey (Moreno \& Meyer, 2016) and mainly terrestrial (though they are good swimmers and climbers) (Carrera-Treviño et al., 2016). They usually sleep during the day in shady areas, on stream banks or on horizontal tree branches (Reid, 2009). Owing to their cryptic habits, jaguars remain less studied than most other large cats (Brodie, 2009), many ecological, reproductive and ethological aspects of this species are poorly understood (Pinho et al., 2014; Harmsen et al., 2017; Miranda et al., 2018); in addition, there are relatively few sightings documented in the literature, despite its wide distribution (Hoogesteijn et al., 2016). At least in Panama, apparently there are no published reports on encounters with jaguars (although there are many anecdotal stories about encounters in rural communities). Thus, in this contribution we make a detailed report about the sighting of a melanistic jaguar in the Darién Province, and notes and illustrations about the event are included. Apparently melanistic jaguars are not common in Panama, although there are some records on both slopes (Figure 1), from sea level to more than 1000 meters (Moreno et al., 2016a, 2016b; Meyer et al., 2019).

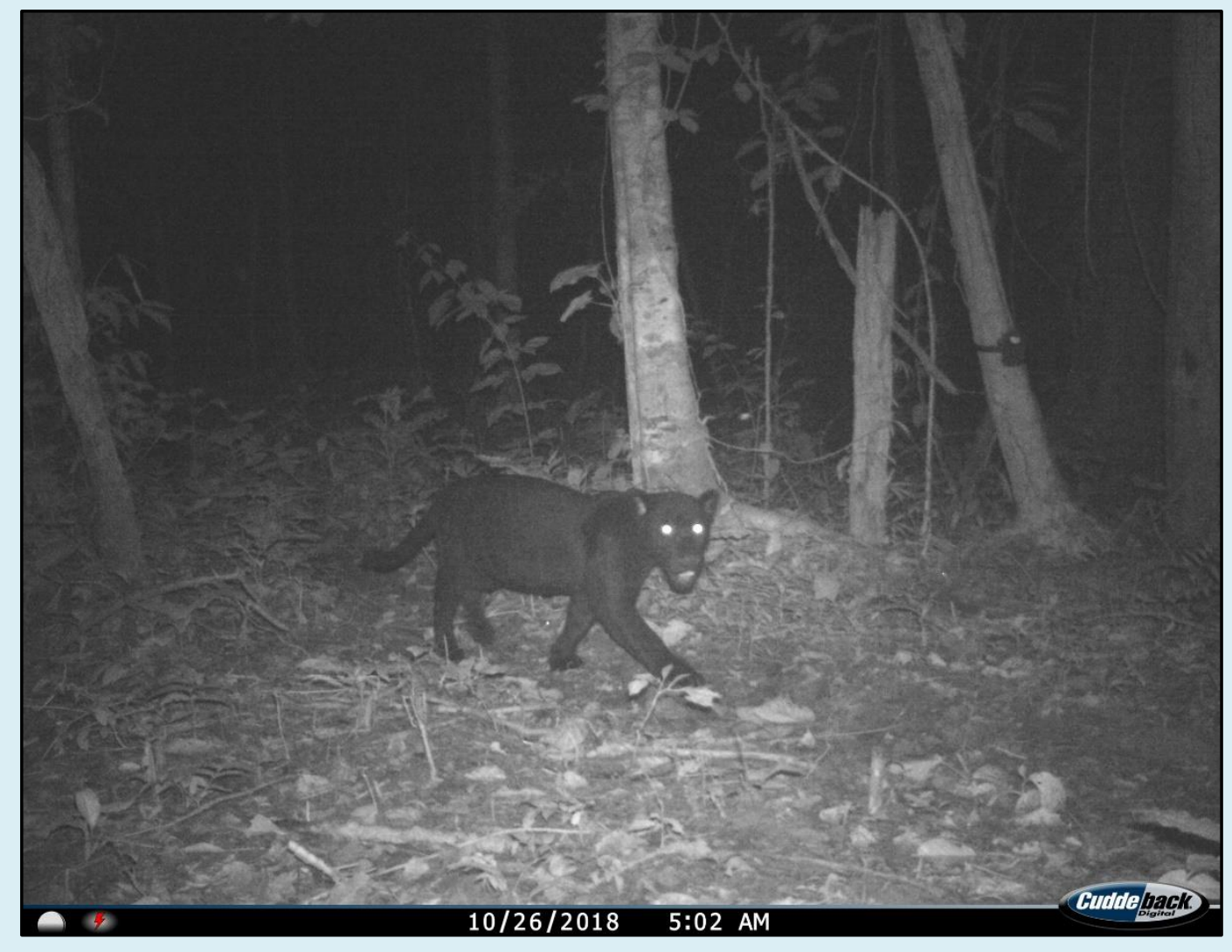

Figure 1. Melanistic jaguar (female) from Bocas del Toro Province, Panama. Photo credits: Fundación Yaguará Panamá/MiAmbiente.

During a botanical expedition, on May 3, 2019, the first and second author of this work (OO and RQ) and two other botanists, began (at 7:30 am) an expedition heading SE from the field station at Cana in Darién ( $7^{\circ} 45^{\prime} 24^{\prime \prime} \mathrm{N}, 77^{\circ} 41^{\prime} 4^{\prime \prime}$ W) to reach Altos del Nique (southern end of the Serranía de Pirre). We walked for eight hours straight along the steep path that leads to the collection site at Altos del 
Nique. At around 3 p.m., two of us (OO and RQ) decided to stay to rest at the base of a large steep hill, located exactly at: $7^{\circ} 45^{\prime} 44^{\prime \prime} \mathrm{N}, 77^{\circ} 43^{\prime} 4^{\prime \prime} \mathrm{W}$ at $1215 \mathrm{~m}$. The site included a forest with well-defined tree strata with extremely steep topography and a very open understory with large trees (between 15 and $40 \mathrm{~m}$ high). Around 3:15 p.m., we heard the sounds of crackling branches and heard a strange purring. Almost immediately, about $5 \mathrm{~m}$ away, we unexpectedly saw a melanistic jaguar descending head-first, down a tree trunk $20 \mathrm{~m}$ high (similar to an Otoba sp., Myristicaceae), as shown in Figure 2 (spoken portrait). When the cat was almost on the forest floor, we felt intimidated, as the jaguar, upon seeing us, let out soft grunts and showed his teeth. Immediately, 00 got up, grabbed a stick and began shouting and waving as one would while trying to scare away an aggressive cat or dog. After this, the jaguar jumped to the forest floor and quickly ran toward a cliff edge with a massive tangle of shrubs. The entire sighting lasted no more than 10 seconds.

Figure 2. Illustration of the jaguar specimen observed in Darién (Serranía de Pirre: Cana). Drawings by Jeraldín Vergara.

We are sure that the observed specimen was a melanistic jaguar, as it was a robust cat (about $2 \mathrm{~m}$ long) with a large head, brown whiskers, relatively small ears, short legs, a relatively short tail (less than head and body length) with black fur and brown towards the tips, and a remarkable musculature on its shoulders. Also, previous camera-trap reports confirm the presence of this species in the area where the sighting took place (Moreno, 2006), which is known as "Pantera conga or Tigre congo". In Panama, the melanistic jaguar could be confused with the yaguarundi (Puma yagouaroundi), but the latter feline differs in having a smaller and slender body, smaller head and a long tail (almost head and body length) (Reid, 2009; Hunter, 2015). A head-first descent from a tree trunk by a jaguar has never been reported in the existing literature, but there are reports of this behavior in the margay (Leopardus wiedii, Sunquist \& Sunquist, 2002; Ried, 2009; Bianchi et al., 2011). Although it is known that jaguars can descend from a tree running as fast as leopards from Africa and Asia, they cannot rotate their joins 180 degrees like the margay (Hunter, 2011). 
It may be that the first author's (00) reaction during the sighting was not the most appropriate, but given the size and presence of the animal in situ, it was very difficult to think clearly about such a situation. Hoogesteijn et al. (2016) has recommended the following actions at the time of an encounter with a jaguar: keep calm (do not shout or make sudden movements) and avoid running or turning your back on the animal (to get away, you must walk slowly backwards at a safe distance of 30 to $40 \mathrm{~m}$ ). Although there are very few documented cases of jaguar attacks on humans (see Rabinowitz, 2005; Campos-Neto et al., 2011; Iserson \& Francis, 2015; Hoogesteijn et al., 2016), there are no known cases of jaguars that deliberately stalked to kill and consume human beings (Hoogesteijn et al., 2016; Moreno et al., 2020). Jaguar's "attacks" on humans are triggered mainly by provocation or accidents with specimens in captivity. In some cases, they can happen due to intrinsic aspects of the animal related to the defense of its cubs, "heat status", the presence of its natural prey and by hunting with dogs, to which the jaguar (or puma), in response to stressors causes accidental attacks (Moreno pers. obs.). The jaguar, unlike its other congeners, has the tendency to avoid confrontation with humans (Hoogesteijn et al., 2016; Moreno et al., 2016b, 2020), and that is exactly our experience in the sighting described here.

The jaguar, erroneously popularly known in the country as "tiger", has historically carried a bad reputation and become part of local myths (mainly the melanistic jaguar due to its dark coloration) (Moreno et al., 2020). This prejudice must be suppressed using environmental education and outreach as tool within communities that live near its habitats. The many folk tales about man-eating jaguars in Panama may represent a social construct driven by highly repetitive and inflated stories that lack officially documented reports (Moreno pers. obs.), as it has happened in other Latin American countries (Marchini, 2014; Kelly, 2019).

\section{ACKNOWLEDGEMENTS}

We are very grateful to Asociación Adopta el Bosque Panamá-Adopt a Panama Rainforest Association (ADOPTA) and Ministerio de Ambiente (MiAmbiente) for financing the field work. Special thanks go to Prof. Jerry Harrison and Dr. Julio Castillo for their revisions and suggestions and Jeraldín Vergara (University of Panama) for the illustrations. Both 00 and RQ thank Rodolfo Flores and Abel Batista for encouraging the publication of this contribution.

\section{REFERENCES}

BIANCHI, R., ROSA, A.F., GATTI, A. \& MENDES, S.L. 2011. Diet of margay, Leopardus wiedii, and jaguarundi, Puma yagouaroundi, Carnivora, Felidae in Atlantic Rainforest, Brazil. Zoologia 28: 127-132.

BRODIE, J.F. 2009. Is research effort allocated efficiently for conservation? Felidae as a global case study. Biodiversity and Conservation 18: 2927-2939.

CAMPOS-NETO, MF, GARRONE-NETO, D. \& HADDAD-JR., V. 2011. Attacks by jaguars (Panthera onca) on humans in central Brazil: report of three cases, with observation of a death. Wilderness Environ. Med. 22(2): 130-135

CARRERA-TREVIÑO, R., CAVAZOS, J.J., BRIONES-SALAS, M. \& LIRA-TORRES, I. 2016. Registro actual del jaguar Panthera onca (Carnivora: Felidae) en el Parque Nacional Cumbres de Monterrey, Nuevo León, México. Revista Mexicana de Biodiversidad 87: 270-275.

HARMSEN, B.J., FOSTER, R.J., SÁNCHEZ, E., GUTIÉRREZ-GONZÁLEZ, C.E., SILVER, S.C., OSTRO, L.E.T., KELLY, M.J., KAY, E. \& QUIGLEY, H. 2017. Long term monitoring of jaguars in the Cockscomb Basin Wildlife Sanctuary, Belize; Implications for camera trap studies of carnivores. PLoS ONE 12(6): e0179505. 
HOOGESTEIJN, R., HOOGESTEIJN, A., TORTATO, F., PAYÁN-GARRIDO, E., JEDRZEJEWSKI, W., MARCHINI, S., VALDERRAMA, C. \& BOEDE, E. 2016. Consideraciones sobre la peligrosidad del jaguar para los humanos. Quién es letal para quién? In: Castaño-Uribe, C., Lasso, C., Hoogesteijn, R. \& Payán-Garrido E. (Eds.). Conflicto entre felinos y humanos en América Latina. Bogotá: Fundación Herencia Ambiental Caribe, Panthera, Instituto de Investigación de Recursos Biológicos Alexander von Humboldt, pp. 445-466.

HUNTER, L. 2011. Carnivores of the World. Princeton/New Jersey: Princeton University Press, 240 p.

HUNTER, L. 2015. Wild Cats of the World, 1st Ed. London: Bloomsbury, 240 p.

ISERSON, K.V. \& FRANCIS, A.M. 2015. Jaguar attack on a child: Case report and literature review. Western Journal of Emergency Medicine 16(2): 303-309.

JĘDRZEJEWSKI, W., CARREÑO, R., SÁNCHEZ-MERCADO, A., SCHMIDT, K., ABARCA, M., ROBINSON, H. S., BOEDE, E.0., HOOGESTEIJN, R., VILORIA, A.L., CERDA, H., VELÁSQUEZ, G. \& ZAMBRANO-MARTÍNEZ, S. 2017. Human-jaguar conflicts and the relative importance of retaliatory killing and hunting for jaguar (Panthera onca) populations in Venezuela. Biological Conservation 209: 524-532.

JĘDRZEJEWSKI, W., ROBINSON, H.S., ABARCA, M., ZELLER, K.A., VELASQUEZ, G., PAEMELAERE, E.A.D., GOLDBERG, J.F., PAYAN, E., HOOGESTEIJN, R., BOEDE, E.O., SCHMIDT, K., LAMPO, M., VILORIA, A.L., CARREÑO, R., ROBINSON, N., LUKACS, P.M., NOWAK, J.J., SALOM-PÉREZ, R., CASTAÑEDA, F., BORON, V. \& QUIGLEY, H. 2018. Estimating large carnivore populations at global scale based on spatial predictions of density and distribution - Application to the jaguar (Panthera onca). PLoS ONE 13(3): e0194719.

KELLY, J.R. 2019. A Sociocultural Perspective: Human Conflict with Jaguars and Pumas in Costa Rica. Conservation and Society 17(4): 355-365.

KITCHENER, A.C., BREITENMOSER-WÜRSTEN, CH., EIZIRIK, E., GENTRY, A., WERDELIN, L., WILTING, A., YAMAGUCHI, N., ABRAMOV, A.V., CHRISTIANSEN, P., DRISCOLL, C., DUCKWORTH, J.W., JOHNSON, W., LUO, S.-J., MEIJAARD, E., O'DONOGHUE, P., SANDERSON, J., SEYMOUR, K., BRUFORD, M., GROVES, C., HOFFMANN, M., NOWELL, K., TIMMONS, Z. \& TOBE, S. 2017. A revised taxonomy of the Felidae. The final report of the Cat Classification Task Force of the IUCN/ SSC Cat Specialist Group. Cat News Special Issue 11, 80 p.

MARCHINI, S. 2014. Who's in conflict with whom? Human dimensions of the conflicts involving wildlife. In: Verdade, L.M., Lyra-Jorge, M.C. \& Piña, C.I. (Eds.). Applied Ecology and Human Dimensions in Biological Conservation. Heidelberg: Springer, pp. 189-209.

MEYER, N., ESSER, H.J., MORENO, R., VAN LANGEVELDE, F., LIEFTING, Y., OLLER ROS, D., VOGELS, C.B.F., CARVER, A.D., NIELSEN, C.K. \& JANSEN, P.A. 2015. An assessment of the terrestrial mammal communities in forests of central Panama, using camera-traps surveys. Journal for Nature Conservation 26: 28-35.

MEYER, N., MORENO, R., SÁNCHES, E., ORTEGA, J., BROWN, E. \& JANSEN, P.A. 2016. Do protected areas in Panama support intact assembages of ungulates? Therya 7: 65-76.

MEYER, N., MORENO, R., SUTHERLAND, C., DE LA TORRE, J.A., ESSER, H., JORDAN, C., OLMOS, M., ORTEGA, J., REYNA HURTADO, R., VALDES, S. \& JANSEN. P. 2019. Effectiveness of Panama as an intercontinental land bridge for large mammals. Conservation Biology 1-13.

MIAMBIENTE. 2016. Resolución $\mathrm{N}^{\circ}$ DM-0657-2016. Available from: http://miambiente.gob.pa/images/documentos_temporales/ESPECIES\%20AMENAZADAS\%202016\%20GAC ETA\%2028187-A-2.pdf (accessed 12 May 2019).

MIRANDA, E.B.P., JÁCOMO, A.T.A., TÔRRES, N.M., ALVES, G.B. \& SILVEIRA, L. 2018. What are jaguars eating in a half-empty forest? Insights from diet in an overhunted Caatinga reserve. Journal of Mammalogy 99(3):724731. 
MORENO, R. 2006. Parámetros poblacionales y aspectos ecológicos de los felinos y sus presas en Cana, Parque Nacional Darién, Panamá. Master's thesis, Heredia: Instituto Internacional en Conservación y Manejo de Vida Silvestre, $135 \mathrm{p}$.

MORENO, R., MEYER, N., OLMOS, M., HOOGESTEIJN, R. \& HOOGESTEIJN, A.L. 2015. Causes of jaguar killing in Panama - a long term survey using interviews. Cat news 62: 40-41.

MORENO, R., BUSTAMANTE, A., MÉNDEZ-CARVAJAL, P. \& MORENO, J. 2016a. Jaguares (Panthera onca) en Panamá; estado actual y conservación. In: Medellín, R.A., de la Torre, J.A., Chávez, C., Zarza, H. \& Ceballos G. (Eds.). El Jaguar en el Siglo XXI: La Perspectiva continental. México: Fondo de la Cultura, pp. 211-239.

MORENO, R., VALDÉS, S., ARTAVIA, A., YOUNG, N., ORTEGA, J., BROWN, E., SÁNCHES, E. \& MEYER, N. 2016b. Conflicto entre felinos y humanos en Panamá: avances en la resolución del conflicto, educación y conservación del jaguar. In: Castaño-Uribe, C., Lasso, C., Hoogesteijn, R. \& Payán-Garrido E. (Eds.). Conflicto entre felinos y humanos en América Latina. Bogotá: Fundación Herencia Ambiental Caribe, Panthera, Instituto de Investigación de Recursos Biológicos Alexander von Humboldt, pp. 61-72.

MORENO, R., YOUNG, Y. \& PUERTES, A. 2020. Guía de promotores ambientales. Primera edición. Panamá: Fundación Yaguará Panamá, Programa de las Naciones Unidas para el Desarrollo (PNUD) and Programa de Pequeñas Donaciones del Fondo para el Medio Ambiente Mundial (FMAM), 84 p.

MORENO, R. \& MEYER, N. 2016. El jaguar (Panthera onca) en la serranía de Pirre, Parque Nacional Darién. Informe final de monitoreo 2014-2016. Proyecto Plan de Implementación 2013 - 2016 del Plan Estratégico del Fondo Darién. Componente (LE) 2. - Conservación, Valoración Ecológica y Divulgación de la Biodiversidad del PND. Panamá: GEMAS-Fundación Natura, Fondo Darién, 33 p.

LOPEZ-GONZÁLEZ, C.A.L. \& MILLER, B.J. 2002. Do jaguars (Panthera onca) depend on large prey? Western North American Naturalist 62: 218-222.

PINHO, G.M., FONSECA, R. \& FARIAS, I.P. 2014. An opportunity for testing multiple paternity in a wild Jaguar (Panthera onca). Biota Neotropica 14(3): e20140055.

POLISAR, J., MAXIT, I., SCOGNAMILLO, D., FARRELL, L., SUNQUIST, M.E. \& EISENBERG, J.F. 2003. Jaguars, pumas, their prey base, and cattle ranching: ecological interpretations of a management problem. Biological Conservation 109: 297-310.

QUIGLEY, H., FOSTER, R., PETRACCA, L., PAYAN, E., SALOM, R. \& HARMSEN, B. 2017. Panthera onca. The IUCN Red List of Threatened Species 2017: e.T15953A123791436. Available from: http://doi.org/10.2305/IUCN.UK.2017-3.RLTS.T15953A50658693.en. (accessed 12 May 2019).

RABINOWITZ, A. 2005. Jaguars and livestock: living with the world's third largest cat. In: Woodroffe, R., Thirgood, S.J. \& Rabinowitz, A. (Eds.). People and wildlife: Conflict or co-existence. Cambridge: Cambridge University Press, pp. 278-285.

REID, F.A. 2009. A Field Guide to the Mammals of Central America \& Southeast Mexico. 2nd ed. New York: Oxford University Press, $346 \mathrm{p}$.

SANDERSON, E.W., REDFORD, R.H., CHETKIEWICZ, C.B., MEDELLIN, R., RABINOWITZ, A., ROBINSON, J. \& TABER, A. 2002. Planning to save a species: the jaguar as a model. Conservation Biology 16: 58-72.

SEYMOUR, K.L. 1989. Panthera onca. Mamm. Species 340: 1-9.

SILVER, S.C., OSTRO, L.E.T., MARSH, L.K., MAFFEI, L., NOSS, A.J., KELLY, M.J., WALLACE, R.B., GOMEZ, H. \& CRESPO, G.A. 2004. The use of camera traps for estimating jaguar (Panthera onca) abundance and density using capture/recapture analysis. Oryx 38(2): 148-154. 
SUNQUIST, M. \& SUNQUIST, F. 2002. Wild Cats of the World. Chicago and London: University of Chicago Press, $452 \mathrm{p}$.

WOZENCRAFT W.C. 2005. Order Carnivora. In: Wilson, D.E. \& Reeder, D.M. (Eds.). Mammal species of the world. A taxonomic and geographic reference, 3rd ed. Baltimore: Johns Hopkins University Press, pp. 532-628.

ZELLER, K. 2007. Jaguars in the new millennium data base update: the state of the jaguar in 2006. New York: Wildlife Conservation Society-Jaguar Conservation Program, 77 p.

Citar como: Ortiz, O., Quijano, R., Fuentes, R., Berguido, G. \& Moreno, R. 2020. Report of a serendipitous encounter with a melanistic Jaguar in Darién (3 May 2019). Mesoamericana 24(1):3440. 